\title{
Hebrew Headstone Inscriptions at Zagreb's Mirogoj Cemetery
}

\begin{abstract}
Since the opening of a central Zagreb cemetery at Mirogoj in 1876, one of its four sections was set aside for Israelite (Jewish) community. Some of the graves in this section, 52 of them, bear inscriptions in Hebrew. The nature of the inscriptions vary, from mere mention of the first and last names, kinship, date of death and age to short poetic texts that sometimes incorporate first names as acrostics. This paper deals with the diachronic incidence of inscriptions, with an analysis of first names appearing on the inscriptions, and an analysis of the surnames mentioned. Some discrepancies between the existing data are highlighted and texts that mention no name in particular are quoted.
\end{abstract}

\section{The First Jewish Settlers in Zagreb}

The oldest document (a court file) referring to a Jew in Zagreb (Elias Judaeus) dates back to $1355^{1}$ (GOLDSTEIN 1994: 293). The documents provided by the Croatian historian Ivan Krstitelj Tkalčić (1840-1905) in his book Povjestni spomenici slob. kralj. grada Zagreba priestolnice Kraljevine dalmatinsko-hrvatsko-slavonske (1889-1905) [Historical Documents of the Free Royal City of Zagreb, the Capital of the Kingdom of Dalmatia-Croatia-Slavonia (1889-1905)] confirm that in the $15^{\text {th }}$ century several Jewish families were living in Gradec, the western, municipal part of Zagreb, providing information on the existence of a "domus Judeorum" in Zagreb in the $15^{\text {th }}$ c. ${ }^{2}$ (GOLDSTEIN 1994: 295), as well as the names of several Jews found in court documents. However, no evidence has been found that there was a Jewish Community established in the city in those days (SCHWARZ 1939: 7). The small community in Gradec came to an end in mid- $15^{\text {th }} \mathrm{c}$. when all of the Jews were expelled from the city (GOLDSTEIN 1994: 296-297; GOLDSTEIN 2004: 14). Thereafter, as a consequence of all of the

1373 according to Kronologija židovstva u Hrvatskoj. There are two more mentions of Zagreb Jews by name in the $14^{\text {th }}$ century: Moše, father of a certain Jona applied for the registration of his property in Vienna in 1384 and 1397, while the widow of Jakov the Jew had to be paid a debt within 15 days in 1355 (GOLDSTEIN 1994: 294).

$2 \quad$ Kronologija židovstva u Hrvatskoj mentions a burglary that occurred there in 1444. 
restrictions put upon Jews in the Habsburg Monarchy, there were no permanent Jewish residents in Zagreb for roughly three centuries.

Pursuant to an Imperial Patent, Zagreb became a unified city on September 7, 1850, by incorporating the royal free city on Gradec Hill, the diocesan settlement of Kaptol, Nova Ves and Vlaška Ves, and all of the suburbs and villages belonging to the aforementioned places. Accordingly, when the first "tolerated" Jews settled in Zagreb at the end of the $18^{\text {th }} \mathrm{c}$., they still had to apply for a permit to settle either from the city magistrate in Gradec or from the bishop on Kaptol, ${ }^{3}$ depending on the part of the city in which they intended to reside (SCHWARZ 1939: 9; DOBROVŠAK 2007: 120; GOLDSTEIN and GOLDSTEIN 2012: 263).

The first such Jew who moved to Zagreb in $1787^{4}$ was Jakov/Jakob Stiegler from the West Moravian town of Třebíč (Germ. Trebitsch) (SCHWARZ 1939, table between pages 8 and 9; GOLDSTEIN 1994: 298; DOBROVŠAK 2007: 83). His residence permit was issued in the following year (SCHWARZ 1939: 9; GOLDSTEIN 1994: 298; GOLDSTEIN 2004: 14; DOBROVŠAK 2007: 83; GOLDSTEIN and GOLDSTEIN 2012: 294). In 1789, Elias Herschl and Jakov Weiss, both from the municipality of Rechnitz (Hung. Rohonc, Cro. Rohunac) in Burgenland, Josephus Fisher from the city of Miskolczino (today's Miskolc) in northern Hungary, and Jakov (Jacobus) Stern from the village of Lübenau in Pomerania (today's Lubiki in Poland) came to live in Zagreb (SCHWARZ 1939: 9, 13. GOLDSTEIN 2004: 14; DOBROVŠAK 2007: 83). These first Jewish settlers engaged predominantly in retail trade, opening small shops or stalls (Dobrovšak 2007: 84). At the beginning of the $19^{\text {th }}$ century only nine Jewish families lived in Zagreb ${ }^{5}$ (GOLDSTEIN 1994: 298; GOLDSTEIN 2004: 14-15; DOBROVŠAK 2007: 130).

Despite the division of the city government, and probably due to their small number - only 20 families - Zagreb's Jews formed a unique Jewish community in 1806 (SCHWARZ 1939: 9; GOLDSTEIN 1994: 298; DOBROVŠAK 2007: 129, 171; GOLDSTEIN and GOLDSTEIN 2012: 240, 294) with seventy-five members, while three years later Zagreb received its first rabbi, Aron Palotta (GOLDSTEIN 1994: 298; GOLDSTEIN 2004, 14; DOBROVŠAK 2007; pp. 130-131, 146).

The first censuses of Zagreb's Jews available to us date to $1808^{6}$ for the municipal jurisdiction (SCHWARZ 1939, table between pp. 8 and 9) and 1812 for

3 The oldest such application preserved in Zagreb is that of the merchant Jakov Friedländer, addressed to Bishop Maksimilijan Vrhovac on 12 September, 1817 (DOBROVŠAK 2007: 106-107).

4 Kronologija židovstva u Hrvatskoj adds "after 300 years the first Jews settled in Zagreb".

5 The census of Jewish families under municipal jurisdiction provided by Gavro Schwarz in the table between pages 8 and 9 indeed mentions nine families, but the census of Jewish families under diocesan jurisdiction from 1812 in the same source (SCHWARZ 1939: 13), mentioning a further eight families must also be taken into consideration.

6 Schwarz in one location (1939: 10) mistakenly quotes 1908 as the year when the census was conducted, however in the following text he mentions the correct year, 1808 . 
the diocesan jurisdiction (SCHWARZ 1939: 13). In the municipal census sixty individuals are listed, out of which fifty-two are Jews, with nineteen more listed under the diocesan jurisdiction, making a total of seventy-one Jews in the entire city. The settling of Jews in Zagreb was a rather slow process due to the timeconsuming administrative procedure required to obtain a residence permit: in a mere quarter of a century, only seventeen families were permitted to live in Zagreb (SCHWARZ 1939: 12. GOLDSTEIN 2004: 14; DOBROVŠAK 2007: 120).

\section{Jewish cemeteries in Zagreb}

By the second half of the $19^{\text {th }}$ century, each Catholic parish in Zagreb had its own cemetery. In 1876, there were ten such cemeteries (in a city of approximately 24,000 inhabitants, KOSIĆ 1974: 10). As far as the "heterodox" were concerned, they could not have been buried in Catholic cemeteries, thus their religious communities had to have their own. In the mid- $19^{\text {th }}$ century, only the Protestants and Muslims did not have their own cemeteries. (The former community was too small, while members of the latter, if any, were probably buried in the places they came from, KOSIĆ 1974: 13-14).

"It was even more difficult for the Israelites (Jews) [than for the Orthodox], who settled in Zagreb in larger numbers in the $19^{\text {th }}$ century, to gain their own rights: in 1811 they opened a cemetery at the foot of Rokov perivoj (Vlaško groblje) and a second one in 1858 in a part of Petrovo groblje" (KOSIĆ 1974: 13). ${ }^{7}$

Thus in 1811, the small Zagreb Jewish Community purchased 100 fathoms of land from Pavao Antolković in order to make themselves a cemetery near the Church of St. Roch (Sveti Rok) at the foot of a hill. The cemetery was named Rokovo groblje, ${ }^{8}$ and it was expanded in 1835 , when Chevra Kadisha ${ }^{9}$ purchased the 450-fathom plot called Mali Tuškanec, which bordered the existing cemetery, from the widow Marija Cezarec (SCHWARZ 1939: 51). The cemetery was extended again in 1844 when an additional 280 fathoms were purchased from Juraj and Agneza Smešnik (SCHWARZ 1939, 41). Burials were performed at Rokovo groblje until the 1860 s, mostly for the deceased who already owned tombs there by the end of that period. The cemetery was closed in 1877, and it is the site called Rokov perivoj, a park with houses, villas and gardens (KOSIĆ 1974: 13. SCHWARZ 1939: 41, 51; DOBROVŠAK 2007: 175).

When the Jews under diocesan jurisdiction seceded from the Community in 1840 because they could not accept innovations introduced in liturgy (thus the

\footnotetext{
7 Translated by Igor Kusin.

8 Kosić (1974: 13) mentions the cemetery at Rokov perivoj as "Vlaško groblje". It would make more sense, however, if that were the name of the other cemetery, the one behind the Church of St. Peter used by the Jews from Vlaška Ves, who were subject to diocesan jurisdiction.

9 Chevra Kadisha in Zagreb was founded in 1785 or 1786 (DOBROVŠAK 2007, 178).
} 
designations "orthodox" and "old-believers"), ${ }^{10}$ Archbishop Juraj Haulik leased them the Zbirec land for use as a cemetery (DOBROVŠAK 2007: 184). The plot was quite distant from the city, so the Jews traded with Stjepan Hranitel for a plot behind the Church of St. Peter. After the reconciliation between the municipal and diocesan Jewish congregations, this cemetery became the property of the common Chevra Kadisha, and was abandoned in 1878 (SCHWARZ 1939: 41, 54; DOBROVŠAK 2007: 175).

The closure of both cemeteries was tied to the opening of a central city cemetery at Mirogoj (KOSIĆ 1974: 13).

On 6 November, 1876, a central city cemetery was inaugurated at Mirogoj, located outside of the city, and owned by the municipality. Every religious community received its own section in the new cemetery without discrimination: Catholics, Orthodox, Protestants and Israelites (Jews, KOSIĆ 1974: 16-17).

Between the years 1879 and 1926, a wall was built on the western and northern sides of the cemetery. On the inside part of the wall there are arcades with tombs for wealthy citizens or those deemed deserving of such a distinguished last resting place by the prevailing politics of a given time. Thus the walls are called the Arcades. The main entrance to the Old Cemetery includes a Roman Catholic chapel, consecrated three years later (KOSIĆ 1974: 18, 34).

Today, the Israelite (Jewish) section of the Old Cemetery at Mirogoj occupies thirteen fields at its south-western end as well as the three southernmost pavilions (915-7) and three fields (924) of the Arcades at its western edge ${ }^{11}$. Of the abovementioned thirteen fields, six $(1,2,3,4,9,10)$ have a rectangular shape with approximate dimensions of $70 \times 45 \mathrm{~m}$ (the first row next to the Arcades), five $(5,6,7,8,11)$ are rectangular with approximate dimensions of $50 \times 45 \mathrm{~m}$ (the second row), while fields 12 and 13 have a more irregular shape, following the cemetery's southern border. ${ }^{12}$

\section{Hebrew Inscriptions at Mirogoj Cemetery}

In the Israelite (Jewish) section of the Old Cemetery at Mirogoj there are 52 graves with Hebrew inscriptions on them, referring to 59 individuals.

Not all of them contain names, dates of death and the age of the individual in question. The shortest inscriptions are those at 2 I 35 containing first names only,

10 To learn more about the schism within the Zagreb Jewish Community, see SCHWARZ 1939: 31-38, GOLDSTEIN 1994: 301and DOBROVŠAK 2007: 182-186.

11 There is another Israelite (Jewish) field, n. 119, at the New Cemetery at Mirogoj.

12 When quoting the data from the Israelite (Jewish) section at the Old Cemetery at Mirogoj, the following system has been employed: field number (1-13) or Arcade field number (915-917, 924), followed by class (I, II/I, II, or ARKVEL, PAVVEL for the Arcades), followed by grave number. 
while the longest is at 3 I 125-6, containing 123 (orthographic) words (including abbreviations) in 24 lines of text.

Only two of the inscriptions are illegible, one because it is lying on the ground and erosion has taken its toll (1 II/I 11; however, the name הדס is still readable), and one because the paint that was used for the letters has worn off (one of the three headstones at 13a II/I 15$)^{13}$.

פ"פט as well as תנצב"ה are not included in this research ${ }^{14}$.

\section{Incidence of Inscriptions}

If we assume that the year of death is identical to the year in which the inscription was made, the oldest one originated in 1877 (924 ARKVEL 4), and the newest in 2007 (13A II/I 55), a range of 130 years.

From the known years of death, the following diachronic representation of inscription occurrence can be constructed:

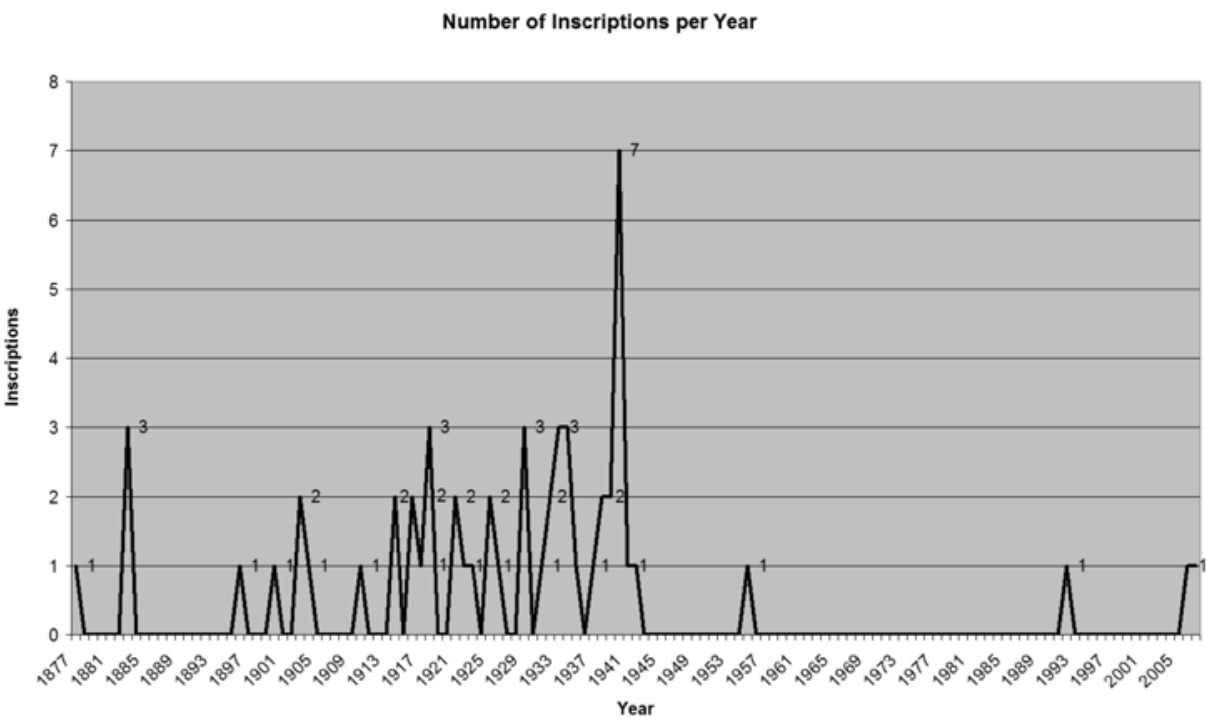

Fig. 1. Incidence of Hebrew inscriptions per year.

13 There are some headstones completely covered by ivy. Some of these may also bear Hebrew inscriptions.

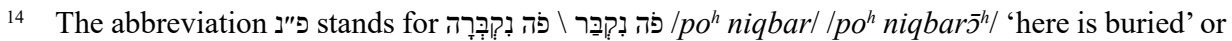

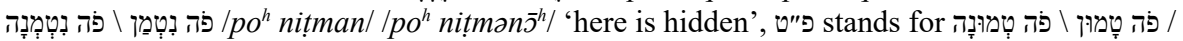

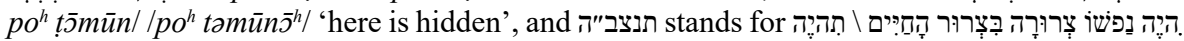

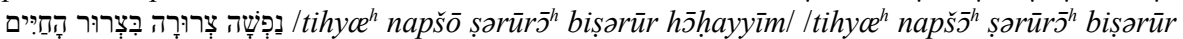
h5̄hayyim/ 'may his/her soul be bound in the bond of everlasting life'. (BLATT 2013; DOCTOR 2008). 
Somewhat deeper insight is provided by grouping the data by decade:

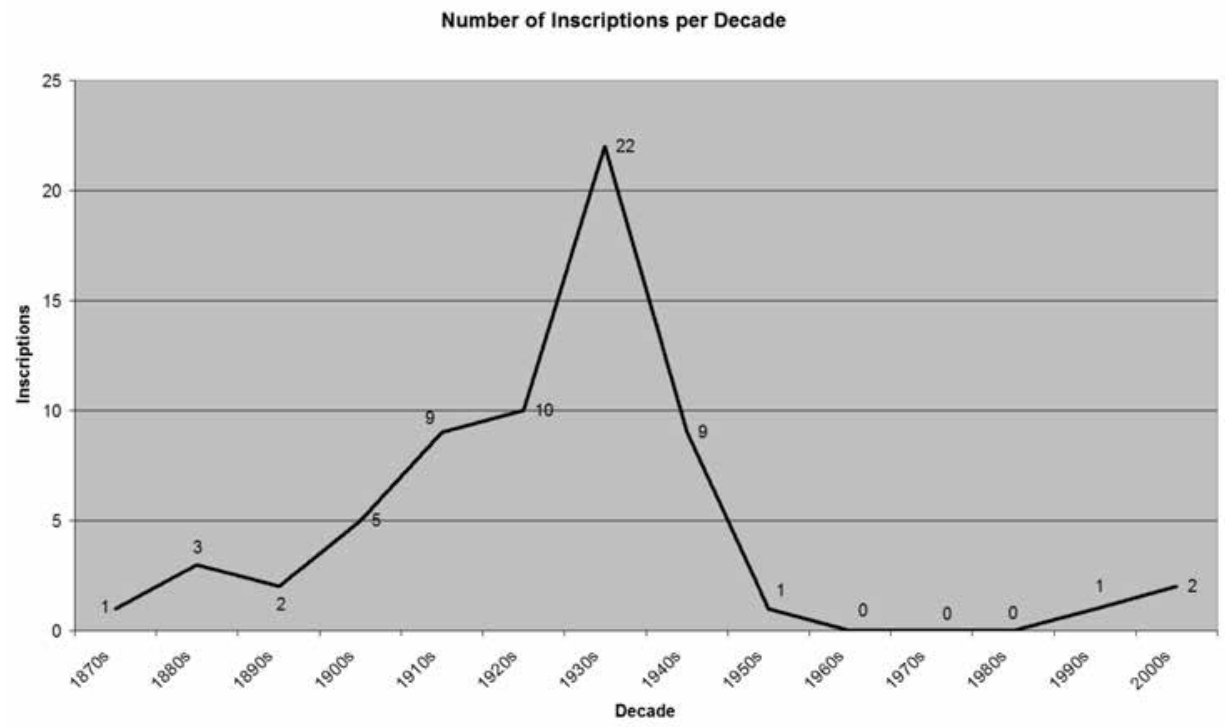

Fig. 2. Incidence of Hebrew inscriptions per decade.

There was a slow increase in the number of inscriptions that peaked in the 1930s (22), reaching its maximum in 1940 (7). Thenceforth, a rapid decline followed during the 1940s (when Croatia was first ruled by the Nazi puppet regime, the so-called Independent State of Croatia, followed by the immediate post-war years) to no inscriptions from 1956 through 1991. In the 1990s, a single inscription appeared (in 1992) and in the 2000s two more (in 2006 and 2007).

The absence of inscriptions from 1956 to 1991 can be explained by the fact that WWII and the Shoah as well as the postwar emigration of Jews decimated the community and, moreover, left it without spiritual guidance. Zagreb had no rabbi for half a century. The last pre-war rabbi, Gavro Schwarz, died in February 1942 , and the new rabbi, Miroslav Šalom Freiberger, was arrested by the Nazi puppet regime, deported and murdered in Auschwitz in 1943 (GOLDSTEIN 2001: 386, 537-538, 540, 656; BRANDL 2016: 95). The leadership of the Community was taken over by two Jews who were not deported because they were married to "Aryan" (non-Jewish) women: Robert Glücksthal and Oskar-Ašer Kišicky (GOLDSTEIN 2001: 540; BRANDL 2015: 682-683). (Both emigrated to Israel in the late 1940s.) The liturgy was continued by Cantor Grüner (GOLDSTEIN 2001: 540; BRANDL 2015: 684). In 1946, Hinko Urbach came to Zagreb and acted as the Community's rabbi for a short period until 1948, when he also emigrated to Israel (URBAH, Hinko / Urbach, Heinrich). The first rabbi appointed to Zagreb after that, Kotel Da-Don, arrived only in 1998 (DA-DON, Kotel). 
Another factor that might explain the lack of Hebrew inscriptions during that time is the secularisation of the Community itself. After World War II, religion was not a vital factor in conducting everyday family life in Yugoslavia. It became possible to declare oneself a non-believer (BRANDL 2015: 689) and all of the ceremonies that had been conducted by religious officials prior to the war-births, naming of children, marriages and divorces, funerals - could be accomplished without a member of a clergy after the war.

\section{First Names}

Forty-nine deceased individuals are mentioned by first name, 28 men and 21 women. All in all, there are 19 different masculine first names and 19 different feminine first names mentioned.

Thirty-one additional individual first names are mentioned, of relatives and other persons involved in the lives of the deceased. The vast majority of them are a deceased person's father (18), with the number of a deceased person's husband being significantly smaller (7). The deceased person's mother is mentioned only three times (3 II 44, 13a II/I 3, 13a II/I 9) and every single time together with the father, never alone. A deceased person's son is mentioned once (3 I 125-6), while a daughter is never mentioned. Accordingly, 28 of these persons bear masculine first names and only 3 of them bear feminine ones. ${ }^{15}$

So in total, we have 56 men bearing 34 different masculine first names (including multiple combinations thereof) and 24 women bearing 22 feminine first names (including multiple combinations thereof) in the inscriptions.

Out of all the masculine first names, only nine have more than a single

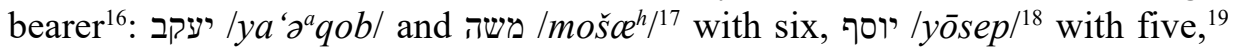

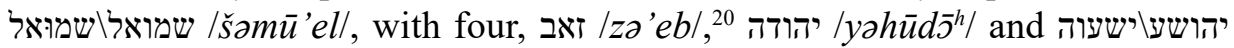

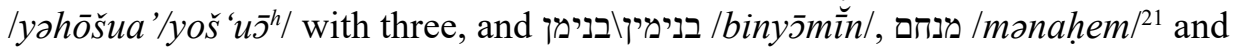

15 These names will be marked with a lower-case $a$ following the location of the grave as described in footnote 12 .

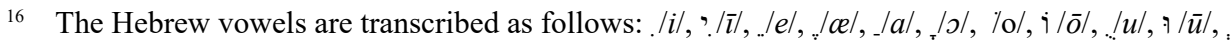
$|\partial|, \ldots \partial^{a} /, \mid \partial^{e} /,{ }_{r} \partial^{o} /$. Being predictable, the aspiration of non-emphatic occlusives that occurs in a postvocalic position (MOSCATI et al. 1964: 26-27) is not specifically marked in the transliterations.

17 The first name משה /moš $e^{h /} /$ also appears in the two-name combination משה דוד /mošce d

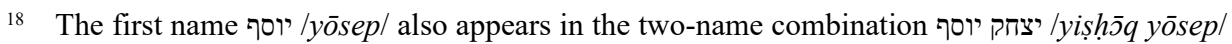
and the three-name combination בן ציון יוסף מאיר /ben șìyōn yōsep me'̄r/.

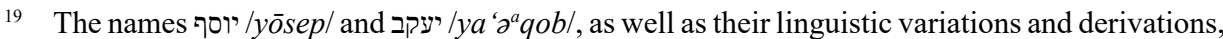
were the two most popular masculine names among Zagreb Jews in the period between the beginning of the $19^{\text {th }} \mathrm{c}$. and WWII.

20 The first name זאב /za'eb/also appears in the two-name combination בנימין זאב /binȳ̄min za'eb/.

21 The first name מחנמ /mənahem/also appears in the two-name combination יבצ מחנמ /monahem șəbi/. 
שלמה /šalomo ${ }^{h}$ / with two. All of the other masculine first names and multiple first name combinations appear on a single headstone each: אברהם /'abrōhs̄m/,

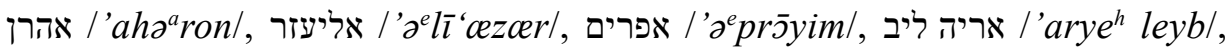

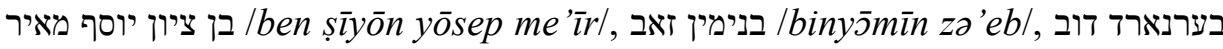

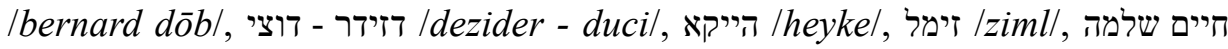

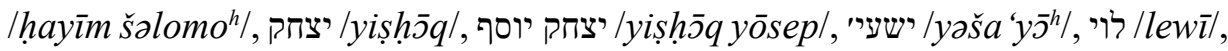

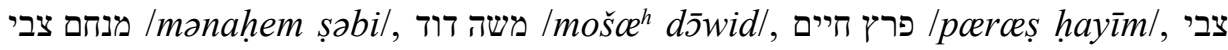

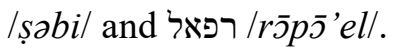

Of all the feminine first names, only three have more than a single bearer: חנה

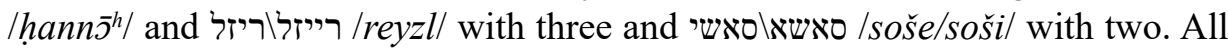
of the other feminine first names and multiple first name combinations appear

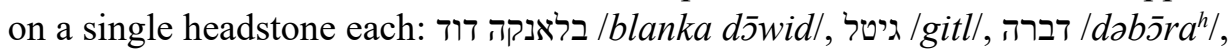

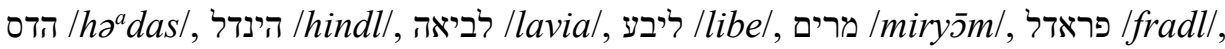

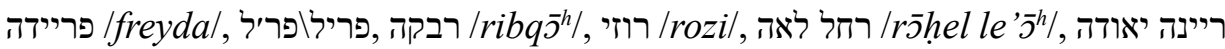

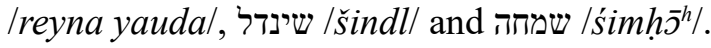

Among the single masculine first names, nineteen are traditional Hebrew ones,

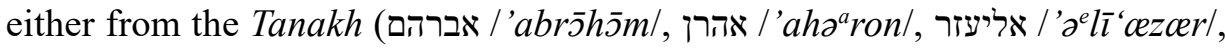

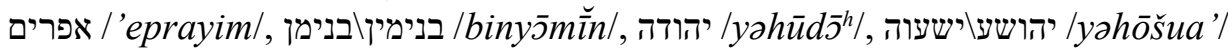

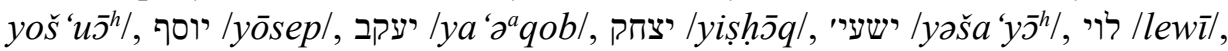

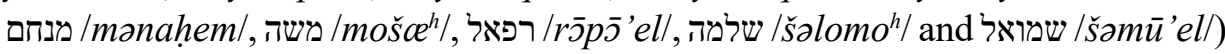
or derived from the metaphors and comparisons in the blessings of Jacob in Gen

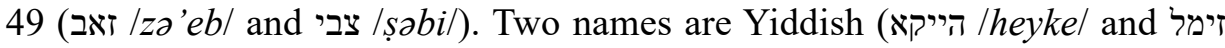
/ziml/), while one single first name derives from the Latin Desiderius, probably via German (דזידר - דוצי/dezider - duci/). There are eight occurrences of two-name combinations, six of them combining two Hebrew names (בנימין זמאבי

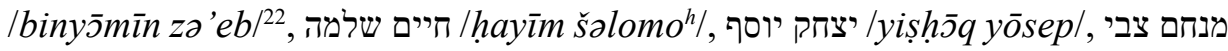

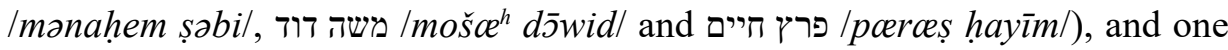
occurrence each of a two-name combination of a Hebrew and Yiddish name in that particular order (אריה ליב /'arye leyb/23), of a two-name combination of a Germanic and a Hebrew name in that particular order (בערנארד דוב-bernard בן ציון יוסף מאיר (אריד דוב /ben șìyōn yōsep me' 'ìr/).

Among the single feminine first names, six are traditional Hebrew ones (שברה

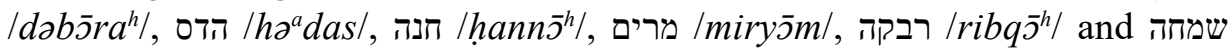

22 According to Gen 49:27 (KJV): " 27 Benjamin shall ravin as a wolf: in the morning he shall devour the prey, and at night he shall divide the spoil."

23 A tautological hybrid name combination of a Hebrew and Yiddish name meaning 'lion'.

24 A tautological hybrid name combination of a Germanic name derived from Proto-Germanic *beran- 'bear' (BEIDER 2001: 287-288; KROONEN 2013: 59-60) and a Hebrew name of the same meaning. 


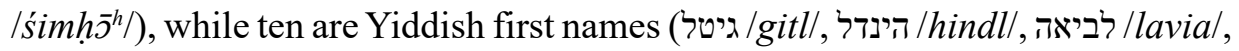

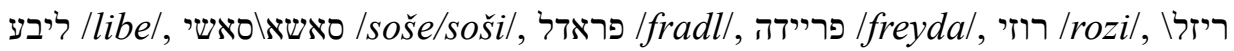

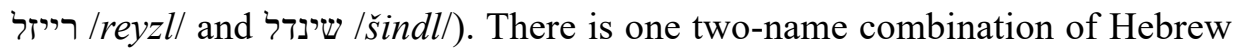
names (רחל לאה /rōhel le' ${ }^{h} /$ ) and two Sephardic two-name combinations, of a Romance and (masculine?) Hebrew firs t name (בלאנקה דוד-/blanka d5̄wid/) and names of Romance and possibly Persian origin (ריינה (רלודה /reyna yauda/) as well as a name whose orthography and etymology are uncertain (פרדיל יאריל or פריל).

Several inscriptions employ the figure of acrostic, a poem in which the initial letters of every verse spell out the name of the person. Thus we have spelled

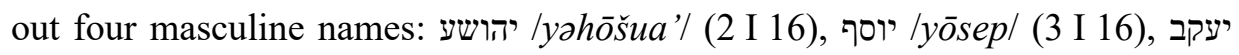

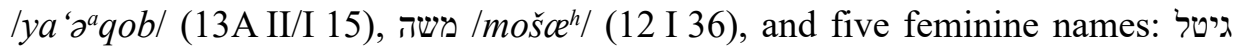

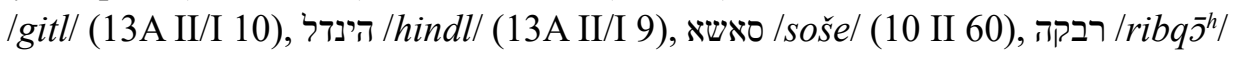
(13 I 4), ריזל/reyzl/ (3 I 15).

\section{Family Names}

Among the Hebrew inscriptions, 27 family names are mentioned.

\begin{tabular}{|c|c|c|}
\hline Oblatt/OBLAT $^{25}$ & /oblatt/ & אן - אָבלאטט \\
\hline Eisenstädter/EISENSTADTER & |eyzenštedter| & אייזענשטעדטער \\
\hline Baš/BASCH & |baš| & באש - - - - - - - 1 \\
\hline BUECHLER & |bixler/ & ביכלער \\
\hline Blatt/BLATT & |blat| & בלאט - - - - - l- lo \\
\hline Bruckner/BRUKNER & /brukner/ & ברוקנר \\
\hline Gaon/GAON & $/ g \bar{y}^{\prime} \bar{o} n /$ & גאון \\
\hline Grossmann/GROSSMAN & /grossman/ & 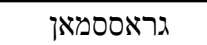 \\
\hline Grünhut/GRUENHUT & |grinhut| & גרינהוט \\
\hline Grünfeld/GRUENFELD & /grinfeld/ & גרינפעלד26 \\
\hline Deutsch/DEUTSCH & $\mid$ daytšs| & דייטש27 \\
\hline Hirschl & |hiršll & הירשל \\
\hline Lewy/Levi/LOWY & |halewī| & הלוי \\
\hline
\end{tabular}

25 The family names written in capital letters are those retrieved from the database of the Zagreb cemetery administration (Gradska groblja) accessible on-line (Tražilica pokojnika). The others are from the tombstones themselves or other sources, including Schwarz and birth registers (Matične knjige rođenih). In the database several typos are notable, probably due to erroneous transcription of old hand-written documents, probably even in Blackletter (Gothic) Cursiva script, by people who did not know the characters well.

26 Appears on two headstones, 3 I 15 and 3 I 16.

27 Appears on three headstones, 1 I 4, 5 II/I 1 and 5 II/I 2. 


\begin{tabular}{|c|c|c|}
\hline Schiller/SCHILLER & |halewìl & 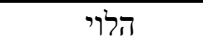 \\
\hline HESSEL & /hessel/ & העססעל \\
\hline HERŠKOVIĆ & /herškowitš/ & הערשקאוויטש28 \\
\hline Weissmann/WEISSMAN & /weysman/ & ווייסמאן \\
\hline Weitzner/WEITZNER & /weycner/ & ווייצנער \\
\hline LEDERER & /lederer/ & לעדערער \\
\hline \multirow[t]{2}{*}{ Mandolfo/MANDOLFO } & /mandolfo/ & מאנדולפו \\
\hline & /nayfeld/ & נייפעלד30 \\
\hline \multirow[t]{2}{*}{ ENGELSRATH } & |engelsrath/ & ענגעלסראטה \\
\hline & |pallotal & פאללאטאי \\
\hline Kohn/KOLIN & /kohn/ & 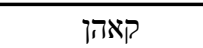 \\
\hline $\begin{array}{l}\text { ROTHSTEIN } \\
\end{array}$ & |rothšteyn/ & ראטהשטיין \\
\hline Rechnitzer/RECCHMITZER & /rexnicer/ & רעכניטצער \\
\hline Steinhardt/STEINHARDT & /šteynhart/ & שטיינהארט \\
\hline Štern/ŠTERN & $/ \check{s} t(e) r n /$ & שטרן \\
\hline Kastl/KASTL & |talewī| & 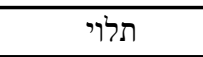 \\
\hline
\end{tabular}

Most of the family names are of Ashkenazi origin and adhere to the Yiddish orthography as used today, but there are exceptions among them. The family names גראססמאן /grossman/ העססעל /oblatt/ העבלטט /hessel/ reveal geminates, typical of German orthography, but a geminate is consistently ignored in the suffix מאן-/-man/. Within the family name אייזענשטעדטער > /eyzenštedter/we can find the digraph $<0 \uparrow>/ d t /$ marking a devoiced consonant that could be rendered simply as $\langle\boldsymbol{v}>|t|$. However, there is no appropriate digraph in the family name שטיינהארט /šteynhart/. Another digraph $<$ ט $>/ t h /$, reflecting the older orthography for the sound [t] is written in the family names ענגעלסראטה /engelsrath/ and ראטיין /rothšteyn/, although here too a $<\boldsymbol{v}>\mid t /$ would suffice.

When transcribing the family name Kohn, every Latin letter was transliterated into its Hebrew counterpart, so the result was קאהן /kohn/, although the $<h>$ is never pronounced, but prolongs the preceding vowel. In the family name שטרן $/ s t(e) r n /$ the vowel /e/ is not explicitly rendered as $\langle y\rangle$, as is the custom in Yiddish, but is left unmarked as is the case in Hebrew orthography.

Three family names are of Hebrew origin: The family name גאון /ḡōon/, popular among the Sephardim, is spelled according to the original, Hebrew orthography, just like the family names הלוי /hallewī/ and תלוי /talewī/, both derived from the

\footnotetext{
28 Appears twice on the same headstone, 13A II/I 15.

29 Appears twice on the same headstone, 3 I 125-126.

30 Mentioned in the inscription at 3 I 125-6.

31 Mentioned in the inscription at 3 I 125-6.
} 
Hebrew first name לו̣ /lewī/. At the same time, the latter two are different from the corresponding "civic" family names, Schiller and Kastl respectively, indicating the Levite ancestry of the families.

The etymology of one family name, פאללאטא /pallota/, is uncertain. One possibility is that it is derived from the name of the village of Palota, today in Slovakia, and the other that it is derived from the first name /palțī el/ from Num 34:26 (GUGGENHEIMER and GUGGENHEIMER 1992: 574.).

Another family name, מאנדולפו /mandolfo/, is an Italian name of Germanic origin and written according to an orthography that is typical not just of Hebrew, but also Judeo-Spanish, some variants of Yiddish as well as certain other Jewish languages: the vowel $/ o$ / is written by the mater lectionis $<1>$.

The Sephardim were recorded rather late in Zagreb. In the $19^{\text {th }}$ century birth registries, there are only two Sephardi family names, both the maiden names of mothers of new-born babies registered: Elvire Eisenstädter née Camis (1334/1889, 45/1892 ${ }^{32}$; FAIGUENBOIM, VALADARES and CAMPAGNANO 2003: 217) and Lisi/Lise Groskopf/Grosskopf née Kabili (874/1880, 940/1881; Faiguenboim, Valadares and Campagnano 2003: 215). Although individual Sephardim began settling in Zagreb since the end of the $19^{\text {th }}$ century, a larger-scale immigration became notable after the formation of the Kingdom of Serbs, Croats and Slovenes in 1918 (GOLDSTEIN 2004: 189), when Zagreb Jews, until then immigrating from and keeping in touch with almost exclusively Ashkenazi communities in Central Europe, found themselves sharing a state with large Sephardi communities in the lands of the former Ottoman Empire ${ }^{33}$.

Unlike the Sephardim, Italian Jews were present in Zagreb from an early date. ${ }^{34}$ They bore different family names, some of them of a clear Ashkenazi origin, like Pri(e)ster, others typically Sephardi like Luz(z)atto, and the rest, like our Mandolfo, Italian ones (Cuzzi, d'Italia, Finzi, Gentilli, Grillo, Recanati, Senigaglia, Tolentino, Venezian). Most of them came to Zagreb from the same region - Gorizia,

32 In providing the data from birth registers stored in the Croatian State Archives, the first number is the year in which the individual was introduced into the registry, followed by the ordinal number under which this was done. The year in which an individual is introduced into a registry does not necessarily have to be the birth year of the individual as there are several cases of belated birth registration (Matične knjige rođenih).

33 The Autonomous Jewish Confessional Community of the Sephardi Rite (Autonomna jevrejska vjeroispovjedna općina sefardskog obreda) in Zagreb was established in the autumn of 1926 and officially recognised a year later. In 1931, the number of Sephardim in Zagreb was estimated at 450. A separate Sephardi Chevra Kadisha was established only in 1939. To learn more about the Sephardim in Zagreb between the two World Wars, see GOLDSTEIN 2004: 189-194.

34 According to Schwarz (1939: 84-85), Emanuel Prister, born in 1814 in Gradisca near Gorizia, settled in Zagreb at around 1847, his brother Girolamo, born in 1825 in Gradisca, settled in Zagreb at around 1854. 
and usually exhibited a certain amount of endogamy, bestowing mostly Italian first names to their own progeny. ${ }^{35}$

\section{Discrepancies and mistakes}

There are differences between some of the dates of death as written in Hebrew numerals on the tombstones and those from other sources, including those written in Arabic numerals on tombstones. For one of the individuals buried in 13 II 22, the Hebrew inscription gives the month of death as טבת תשנ"ב (Tevet, 5752), which corresponds to December 1991 - January 1992. However, the date of death as written in Arabic numerals on the same headstone presents it as 2 December 1992, which would correspond to ז' כסלו תשנ"ג Kislev, 5753), a whole year later. A similar mistake appears on another headstone (13A II/I 16): the date of death in Hebrew numerals is given as (6 Tevet, 5702) - 26 December 1941, while in other sources it appears as 14 December 1942- ו' טבת תש"ג (6 Tevet, 5703), a (Jewish) year later again. On a third headstone (13a II/I 55), there is a mistake of one (Jewish) year as well in the only engraved date of birth in Hebrew numerals: the date is rendered כ"ח בכסלו התרע"ז (25 Kislev, 5677)—23 December 1916, while the same date in other sources is 13 December 1917-ח כסלו תרע"ח (25 Kislev, 5675).

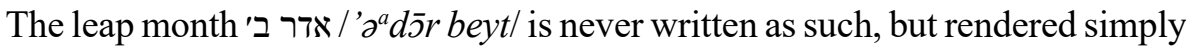

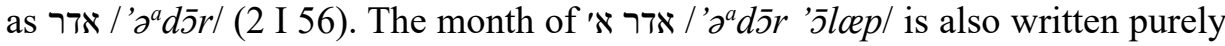
as אדר / אדר / 'כa $\partial^{a} d \bar{s} r$ / (13 II 12).

The second month of the Hebrew civil year and the eighth month of its ecclesiastical year is twice written as חמרחשון /hcešswōn/ (3 I 32, 11 II 84) and once as /marhcešws̄n/ (13a II/I 15).

\section{Hebrew inscriptions not containing names}

There are two monuments dedicated to war victims. One is situated in field 4 and is dedicated to the memory of World War I victims. Its text is in Aramaic: 'the law of the kingdom is the law', meaning that halakhic validity also applies to the law of the state alongside the accepted Jewish halakhic law. The other is located at the southern boundary of the cemetery and is dedicated to the victims of World War II. There is a statue of Moses holding the tablets of the Law, made by Croatian sculptor Antun Augustinčić (1900-1979) (MALEKOVIĆ 1974: 67). The monument is dedicated to the Jewish fighters who perished in World War II and to the victims of the Shoah:

$\overline{35}$ According to the evidence in birth registries (Matične knjige rođenih). 


\section{לזכר הלוחמים היהודים שנפלו במלחמת העולם

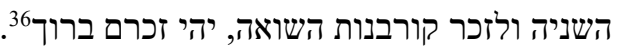

The Hebrew part of the inscription on the headstone 2 II/I 20 reads: פשר בשריה נקברו the complete form of the phrase usually rendered as the abbreviation ${ }^{\prime \prime}{ }^{37}$. The rest is in Latin script.

Several headstones bear texts in the form of a short poem which at the same time is not an acrostic. One is on 4 I 62:

$$
\begin{gathered}
\text { עשה שלום במרומיו } \\
\text { עלינו ועל כל ישרום } 38 \text { ישלאל }
\end{gathered}
$$

Another on 9 II/I 103:

$$
\begin{aligned}
& \text { רק גופם מתו } \\
& \text { ועפרם שב לאדמה הפותו, } \\
& \text { ונשמתם הטהורה לאדמה } \\
& \text { מאיר בבית אל ברמה הטרה } 39
\end{aligned}
$$

The inscription on 12 II 7 could also be qualified as that:

$$
\text { ברוך דין אמתן, יקת לקח }
$$

As could the one on 924 ARKVEL 4:

$$
\text { בשלום ינוחו אשר פה טמונים }
$$

ונשמותיהם תהיינה צרורות פמונים

כצרור החיים

Two headstones bear short inscriptions in Hebrew. Apart from the date of death, on 3 I 32 we can also read

$$
\text { שמות ישראל קדושים42 }
$$

while on $11 \mathrm{II} / \mathrm{I} 21$ we can see

\footnotetext{
36 'To the memory of the Jewish fighters who fell in World War Two and to the memory of the victims of the Holocaust, may their memory be blessed'.

37 See footnote 14.

38 'He made peace in His heights

He will make peace upon us and upon all of Israel'.

39 'Only their bodies died and their ashes returned to the soil, and their pure soul shone in the house of God in Ramah(?)'

40 'The LORD gave, THe LORD took blessed be the judge of truth'

41 'In peace will rest they who are hidden here and their souls will be bundled together like the bundle of life'.

42 'The names of Israel are holy'.
} 


\section{נפש ערניה43}

The grave numbered as 13A II/I 55 bears two plaques that were attached to the headstone. One of them bears the inscription

\section{ליהוה הישועה על-עמך ברכתך סלה44}

as well as the abbreviation ${ }^{45}$ זצרת, located between the person's date of birth and date of death (both in Hebrew numerals), the only time this abbreviation appears at Mirogoj. On the other, the inscription reads

כבודי ומרים ראשי, קולי אל-יהוה אקרא

Appendix $A$

List of Headstones with Hebrew inscriptions

\begin{tabular}{|c|c|c|c|}
\hline Location & First Name & Family Name & Died \\
\hline $1 \mathrm{I} 4$ & יוסף & דייטש & 1883 \\
\hline $1 \mathrm{I} 4 \mathrm{a}$ & יהודה & & \\
\hline $1 \mathrm{II} / \mathrm{I} 11$ & 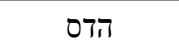 & ברוקנר & 1883 \\
\hline $1 \mathrm{II} / \mathrm{I} 13$ & דברה & הירשל & 1885 \\
\hline $1 \mathrm{II} / \mathrm{I} 13 \mathrm{a}$ & יהודה & & \\
\hline 2 I 16 & יהושע & & 1925 \\
\hline 2 I $16 a$ & יעקב & & \\
\hline 2 I 35 & בנימין & & 1904 \\
\hline 2 I 35 & יוסף & & 1922 \\
\hline 2 I 56 & משה & איזענשטאדטער & 1910 \\
\hline 2 II/I 20 & & & 1903 \\
\hline $2 \mathrm{II} / \mathrm{I} 80$ & יוסף & גרינהוט & 1914 \\
\hline 3 I 15 & ריזל & גרינפעלד & 1916 \\
\hline 3 I 16 & יצחק יוסף & גרינפעלד & 1916 \\
\hline 3 I 32 & & & 1941 \\
\hline 3 I 50 & יחודה & & 1917 \\
\hline 3 I 125 & חנה & לעדערער & 1923 \\
\hline 3 I 126 & שמואל & לעדערער & 1929 \\
\hline 3 I 125-126a & צבי & פאללאטא & \\
\hline 3 I $125-126 a$ & אהרן & נייפעלד & \\
\hline
\end{tabular}

43 'A vigil soul'.

44 'To Yнwh (belongs) the salvation, upon Your people is Your blessing. Selah' (Ps 3:8).

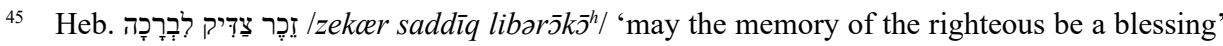
(BLATT 2013; Doctor 2008).

46 'My honour and I hold my head high, my voice to YHWH will call'. 


\begin{tabular}{|c|c|c|c|}
\hline 3 I 125-126a & הייקא & & \\
\hline 3 II 20 & פרץ חיים & תלוי & 1926 \\
\hline 3 II 44 & פריל & & 1938 \\
\hline 3 II 44a & שמואל & & \\
\hline 3 II $44 a$ & שמחה & & \\
\hline \multicolumn{4}{|l|}{4} \\
\hline 4 I 62 & & & 1914 \\
\hline 5 I 27 & יעקב & גראססמאן & 1921 \\
\hline $5 \mathrm{II} / \mathrm{I} 1$ & רייזל & דייטש & 1900 \\
\hline 5 II/I 2 & יעקב & דייטש & 1896 \\
\hline $5 \mathrm{II} / \mathrm{I} 2 \mathrm{a}$ & בנימן & & \\
\hline 7 I 58 & & הלוי & 1918 \\
\hline 7 I 58a & יעקב & & \\
\hline 8 II/I 23 & רוזי & רעכניטזער & $1917 / 1918^{47}$ \\
\hline $8 \mathrm{II} / \mathrm{I} 46$ & מרים & קאהן & 1918 \\
\hline 9 II/I 103 & & & 1925 \\
\hline 9 II/I 111 & משה & שטיינהרט & 1921 \\
\hline 10 I 17 & יוסף & & 1934 \\
\hline 10 I $17 \mathrm{a}$ & משה דוד & & \\
\hline 10 I 24 & בן ציון יוסף מאיר & & 1929 \\
\hline 10 I 24 & זאב & & 1939 \\
\hline $10 \mathrm{I} 24 \mathrm{a}$ & יהושע & & \\
\hline 10 I 121 & חנה & אָבלאטט & 1903 \\
\hline 10 I 121a & שמואל & & \\
\hline 10 I 150 & משה & ביכלער & 1935 \\
\hline $10 \mathrm{I} 150 \mathrm{a}$ & זאב & & \\
\hline 10 II 60 & סאשא & & 1929 \\
\hline 10 II 60a & מנחם צבי & & \\
\hline 10 II 103 & אפרים & בלאט & 1932 \\
\hline 10 II 103a & שמוּאל & & \\
\hline 11 II 84 & פראדל & & 1933 \\
\hline 11 II $84 a$ & משה & & \\
\hline $11 \mathrm{II} 86$ & & & 1934 \\
\hline 11 II 119 & חיים שלמה & ווייצנער & 1937 \\
\hline
\end{tabular}

$47 \quad$ The first is the year written in Arabic numerals on the headstone, and the second is the year in the Gradska Groblja database. 


\begin{tabular}{|c|c|c|c|}
\hline 11 II $119 a$ & מנחם & & \\
\hline $11 \mathrm{II} / \mathrm{I} 21$ & & & 1932 \\
\hline 12 I 36 & משה & מרגל & 1969 \\
\hline 12 I 36a & זימל & & \\
\hline 12 II 7 & & & 1933 \\
\hline 12 II 12 & חנה & מאנדולפו & 1933 \\
\hline 12 II $12 \mathrm{a}$ & רפאל & & \\
\hline 13 I 2 & בלאנקה דוד & גאון & 1940 \\
\hline 13 I 4 & רבקה & ווייסמאן & 1940 \\
\hline 13 II 12 & ריינה יאודה & הלוי & 1940 \\
\hline 13 II 13 & סאשי & & 1940 \\
\hline 13 II 22 & שלמה & שטרן & 1940 \\
\hline 13 II 22 & דזידר - דוצי & שטרן & 1992 \\
\hline 13 II $22 a$ & משה & & \\
\hline 13A II/I 3 & אריה ליב & ראטהשטיין & 1943 \\
\hline $13 \mathrm{~A} \mathrm{II} / \mathrm{I} 3 \mathrm{a}$ & יוסף & & \\
\hline 13A II/I 3a & רחל לאה & & \\
\hline $13 \mathrm{~A} \mathrm{II} / \mathrm{I} 9$ & הינדל & העססעל & 1938 \\
\hline $13 \mathrm{~A} \mathrm{II} / \mathrm{I} 9 \mathrm{a}$ & אליעזר & & \\
\hline 13A II/I 9a & לביאה & & \\
\hline 13A II/I 10 & גיטל & ענגעלסראטה & $1939 / 1940^{48}$ \\
\hline 13A II/I 10a & מנחם & & \\
\hline 13A II/I 10a & בנימין זאב & & \\
\hline $13 \mathrm{~A} \mathrm{II} / \mathrm{I} 15$ & פריידה & הערשקאוויטש & 1939 \\
\hline 13A II/I 15 & יעקב & הערשקאוויטש & 1931 \\
\hline $13 \mathrm{~A} \mathrm{II} / \mathrm{I} 15 \mathrm{a}$ & ישעוה & & \\
\hline 13A II/I 15a & ישעי' ישעי & & \\
\hline 13A II/I 16 & שינדל & באש & $1942 / 1941^{49}$ \\
\hline 13A II/I 16 & ליבע & & \\
\hline 13A II/I 16 & שלמה & & \\
\hline 13A II/I 16 & אברהם & & \\
\hline 13A II/I 16a & יצחק & & \\
\hline
\end{tabular}

48 The first is the year written in Arabic numerals on the headstone, and the second is the year in the Gradska Groblja database.

49 Both years appear on the headstone, the first on in Arabic numerals, and the second in Hebrew numerals (תר"ב). 
Igor Kusin - Hebrew Headstone Inscriptions at Zagreb's Mirogoj Cemetery

\begin{tabular}{|c|c|c|c|}
\hline 13A II/I 16a & & & \\
\hline 13A II/I 55 & & & 2007 \\
\hline 13A II/I 55 & רייזקל & & 2006 \\
\hline 917 PAVVEL 1 & רערנארד דוב & & 1955 \\
\hline 924 ARKVEL 4 & & & 1877 \\
\hline 931 1 & & & \\
\hline
\end{tabular}


Appendix B

Map of the Israelite (Jewish) section of the Old Cemetery at Mirogoj with graves bearing Hebrew inscriptions marked
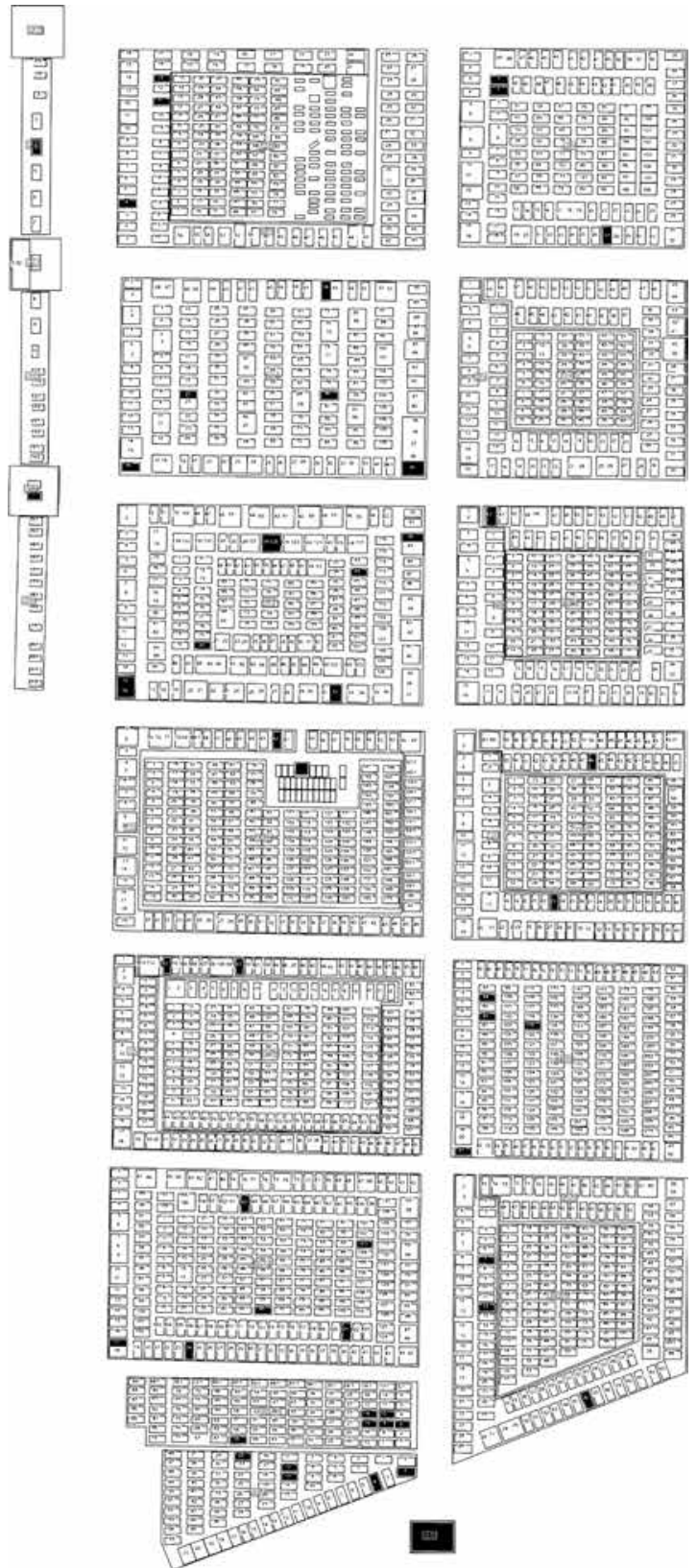

Fig. 3. Graves with Hebrew inscriptions at the Israelite (Jewish) section of Mirogoj Cemetery. 


\section{Bibliography}

BEIDER, Alexander. 1968. A Dictionary of Ashkenazic Given Names: Their Origins, Structure, Pronunciation, and Migrations. Bergenfeld, NJ: Avotaynu.

BLATT, Warren. 2016. Reading Hebrew Tombstones. New York: Museum of Jewish Heritage. http://www.jewishgen.org/InfoFiles/tombstones.html (accessed on 30 December, 2013).

BRANDL, Naida Mihal. 2015. Djelatnost Židovske bogoštovne općine u Zagrebu od 1945. do 1946. godine [Activities of the Jewish Religious Community in Zagreb in 1945 and 1946]. Radovi Zavoda za hrvatsku povijest Filozofskog fakulteta Sveučilišta u Zagrebu, book 47, vol. 2: 675-710. https://hrcak.srce.hr/file/226792 (accessed on 1 May, 2018).

BRANDL, Naida Mihal. 2016. “Židovska topografija Zagreba kojeg više nema” [Topography of Zagreb That Is No More]. Historijski zbornik LXIX, n. 1: 91-103.

DA-DON, Kotel. // Židovski biografski leksikon. Ed. Goldstein, Ivo. http://zbl.lzmk. $\mathrm{hr} / \mathrm{p}=3023$ (accessed on 31 August, 2018).

DOBROVŠAK, Ljiljana. 2007. Razvoj židovskih zajednica u Kraljevini Hrvatskoj $i$ Slavoniji (1783.-1873.) [The Development of Jewish Communities in the Kingdom of Croatia and Slavonia (1783-1873)]. Doctoral dissertation. Zagreb: Filozofski fakultet.

DOCTOR, Ronald D. 2008. Reading Hebrew Matzevot. Key Words, Abbreviations $i$ Acronyms. Portland, OR: Ronald D. Doctor. http://www.rootsweb.ancestry.com/ orjgs/ Abrrev.pdf (accessed on 30 December, 2016).

FAIGUENBOIM, Guilherme, VALADARES, Paulo, CAMPAGNANO, Anna Rosa. 2003. Dicionário sefaradi de sobrenomes inclusive Cristãos-novos, Conversos, Marranos, Italianos, Berberes e sua História na Espanha, Portugal e Itália. Rio de Janeiro: Fraiha.

GOLDSTEIN, Ivo. 1994. "Židovi na Gradecu od 14. stoljeća do 1848. Godine” [Jews in Gradec from the $14^{\text {th }}$ Century until the Year 1848]. In I. Kampuš, L. Margetić and F. Šanjek (eds.), Zagrebački Gradec 1242-1850. [Zagreb's Gradec 1242-1850]. Zagreb: Grad Zagreb: 293-303.

GOLDSTEIN, Ivo. 2001. Holokaust u Zagrebu [The Holocaust in Zagreb]. Zagreb: Novi Liber.

GOLDSTEIN, Ivo. 2004. Židovi u Zagrebu 1918-1941 [Jews in Zagreb 1918-1941]. Zagreb: Novi Liber.

GOLDSTEIN, Ivo and GOLDSTEIN, Slavko. 2012. Povijest grada Zagreba, knjiga 1. Od prethistorije do 1918. [History of the city of Zagreb, book 1 From prehistory until 1918]. Zagreb: Novi Liber.

GUGGENHEIMER, Heinrich W. and GUGGENHEIMER, Eva H. 1992. Jewish Family Names and Their Origins: An Etymological Dictionary. New York City, Jersey City: KTAV Publishing House.

Mirogoj Zagreb. 1974. Ed. Hutinec, Boris. Zagreb: Grafički zavod Hrvatske, Gradska groblja. 
KAMPUŠ, Ivan, MARGETIĆ, Lujo and ŠANJEK, Franjo (eds.). 1994. Zagrebački Gradec 1242-1850. [Zagreb's Gradec 1242-1850]. Zagreb: Grad Zagreb

KOSIĆ, Krešimir. 1974. "Mirogoj između jučer i sutra” [Mirogoj between Yesterday and Tomorrow]. Mirogoj Zagreb. Ed. Hutinec, Boris. Zagreb: Grafički zavod Hrvatske Gradska groblja, 7-55.

KROONEN, Guus. 2013. Etymological Dictionary of Proto-Germanic. Leiden, Boston: Brill.

Kronologija židovstva u Hrvatskoj [Chronology of Jewry in Croatia]. Židovska općina Zagreb. http://www.zoz.hr/home.php?content $=$ content\&term $=9 \&$ key $=3 \& \mathrm{key} 1=4 \& \mathrm{k}$ ey2 $=9$ (accessed on 14. March, 2016).

MALEKOVIĆ, Vladimir. 1974. "Mirogoj galerija umjetnina” [Mirogoj, an Art Gallery]. Mirogoj Zagreb. Ed. Hutinec, Boris. Zagreb: Grafički zavod Hrvatske - Gradska groblja, 57-70.

Matične knjige rođenih 1849-1870 Židovske općine Zagreb [Birth Registrars of the Zagreb Jewish Community 1849-1870]. Hrvatski državni arhiv.

MOSCATI, Sabatino et al. 1964. An Introduction to the Comparative Grammar of the Semitic Languages. Phonology and Morphology. Wiesbaden: Otto Harrassowitz.

SCHWARZ, Gavro. 1939. Povijest zagrebačke židovske općine od osnutka do 50-tih godina 19. vijeka [History of the Zagreb Jewish Community since Its Foundation until the 1850s]. Zagreb: Štamparija Gaj.

Tražilica pokojnika. Zagreb: Gradska groblja. http://www.gradskagroblja.hr/default. aspx?id=382 (accessed on 1 August 2016).

URBAH, Hinko (Urbach, Heinrich). 2018. Židovski biografski leksikon [Jewish Biographical Lexicon]. Ed. Goldstein, Ivo. Zagreb: Hrvatski leksikografski zavod Miroslav Krleža. http://zbl.lzmk.hr/?p=2629 (accessed on 31 August, 2018).

Židovski biografski leksikon [Jewish Biographical Lexicon]. Ed. Goldstein, Ivo. Zagreb: Hrvatski leksikografski zavod Miroslav Krleža. http://zbl.lzmk.hr/ (accessed on 31 August, 2018). 


\section{Židovski nadgrobni natpisi na zagrebačkom groblju Mirogoj}

Od otvaranja središnjeg zagrebačkog groblja na Mirogoju 1876. godine, jedan je od njegovih četiriju odjela bio predviđen da bude izraelitski (židovski). Pedeset dva groba u tom odjelu imaju natpise na hebrejskom jeziku. Priroda natpisa varira od pukog spominjanja imena i prezimena, srodstva, datuma smrti i dobi do kratkih pjesničkih tekstova koji ponekad akrostihom daju imena pokojnika. U članku se obrađuje dijakronijsko pojavljivanje natpisa uz analizu osobnih imena te prezimena koja se pojavljuju na natpisima. Ukazano je na neka razmimoilaženja unutar navedenih podataka, a navedeni su i tekstovi u kojima se ne spominje nijedno ime.

Ključne riječi: nadgrobni natpisi, zagrebački Židovi, hebrejski natpisi, židovska osobna imena, židovska prezimena

Key words: headstone inscriptions, Zagreb Jews, Hebrew inscriptions, Jewish first names, Jewish family names

Igor Kusin

Filozofski fakultet Sveučilišta u Zagrebu Ivana Lučića 3 10000 Zagreb ikusin@ffzg.hr 


\section{FILOZOFSKI FAKULTET SVEUČILIŠTA U ZAGREBU \\ ZAVOD ZA HRVATSKU POVIJEST \\ INSTITUTE OF CROATIAN HISTORY \\ INSTITUT FÜR KROATISCHE GESCHICHTE}

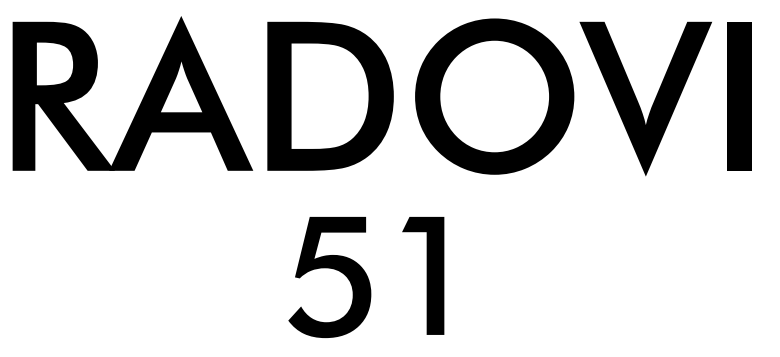

BROJ 2

ZAVOD ZA HRVATSKU POVIJEST

FILOZOFSKOGA FAKULTETA SVEUČILIŠTA U ZAGREBU

\section{FF press}

ZAGREB 2019. 


\title{
RADOVI ZAVODA ZA HRVATSKU POVIJEST FILOZOFSKOGA FAKULTETA SVEUČILIŠTA U ZAGREBU
}

\author{
Knjiga 51, broj 2
}

\author{
Izdavač / Publisher \\ Zavod za hrvatsku povijest \\ Filozofskoga fakulteta Sveučilišta u Zagrebu \\ FF-press \\ Za izdavača / For Publisher \\ Vesna Vlahović Štetić \\ Glavni urednik / Editor-in-Chief \\ Inga Vilogorac Brčić \\ Izvršni urednik / Executive Editor \\ Kornelija Jurin Starčević \\ Uredništvo / Editorial Board
}

Jasmina Osterman (stara povijest/ancient history), Trpimir Vedriš (srednji vijek/medieval history), Hrvoje Petrić (rani novi vijek/early modern history), Željko Holjevac (moderna povijest/ modern history), Tvrtko Jakovina (suvremena povijest/contemporary history), Silvija Pisk

(mikrohistorija i zavičajna povijest/microhistory and local history),

Zrinka Blažević (teorija i metodologija povijesti/theory and methodology of history)

Međunarodno uredničko vijeće / International Editorial Council

Denis Alimov (Sankt Peterburg), Živko Andrijašević (Nikšić), Csaba Békés (Budapest), Rajko

Bratož (Ljubljana), Svetlozar Eldarov (Sofija), Toni Filiposki (Skopje), Aleksandar Fotić

(Beograd), Vladan Gavrilović (Novi Sad), Alojz Ivanišević (Wien),

Egidio Ivetić (Padova), Husnija Kamberović (Sarajevo), Karl Kaser (Graz),

Irina Ognyanova (Sofija), Géza Pálffy (Budapest), Ioan-Aurel Pop (Cluj),

Nade Proeva (Skopje), Alexios Savvides (Kalamata), Vlada Stanković (Beograd),

Ludwig Steindorff (Kiel), Peter Štih (Ljubljana)

Izvršni urednik za tuzemnu i inozemnu razmjenu /

Executive Editor for Publications Exchange

Martin Previšić

Tajnik uredništva / Editorial Board Assistant

Dejan Zadro

Adresa uredništva/Editorial Board address

Zavod za hrvatsku povijest, Filozofski fakultet Zagreb, Ivana Lučića 3, HR-10 000, Zagreb Tel. ++385(0)1 6120191

Časopis izlazi jedanput godišnje / The Journal is published once a year

Časopis je u digitalnom obliku dostupan na / The Journal in digital form is accessible at Portal znanstvenih časopisa Republike Hrvatske „Hrčak“ http://hrcak.srce.hr/radovi-zhp

Financijska potpora za tisak časopisa / The Journal is published with the support by Ministarstvo znanosti, obrazovanja i športa Republike Hrvatske

Časopis je indeksiran u sljedećim bazama / The Journal is indexed in the following databases: Directory of Open Access Journals, EBSCO, SCOPUS, ERIH PLUS, Emerging Sources Citation Index - Web of Science 


\title{
Naslovna stranica / Title page by Marko Maraković
}

\section{Grafičko oblikovanje i računalni slog / Graphic design and layout Marko Maraković}

\author{
Lektura / Language editors \\ Samanta Paronić (hrvatski / Croatian) \\ Edward Bosnar (engleski / English)
}

Tisak / Printed by

Tiskara Zelina, Sv. Ivan Zelina

Naklada / Issued

200 primjeraka / 200 copies

Ilustracija na naslovnici

Muza Klio (Alexander S. Murray, Manual of Mythology, London 1898)

Časopis je u digitalnom obliku dostupan na Portalu znanstvenih časopisa Republike Hrvatske ,Hrčak“ http://hrcak.srce.hr/radovi-zhp

The Journal is accessible in digital form at the Hrcak - Portal of scientific journals of Croatia http://hrcak.srce.hr/radovi-zhp 